\title{
Impact of hydrolysis lignin on phytosanitary condition of soils during potato cultivation
}

\author{
Andrey A. Komarov ${ }^{*}$, Aleksey A. Komarov ${ }^{2}$, Pavel A. Suhanov ${ }^{1}$, Oleg A. Malafeyev ${ }^{3}$, and \\ Bakyt $R$. Irmulatov ${ }^{4}$ \\ ${ }^{1}$ Russian agrophysical research Institute, 195220 Saint Petersburg, Russia \\ ${ }^{2}$ Research Institute of agriculture in Leningrad "Belogorka", 188338 Belogorka, Russia \\ ${ }^{3}$ Saint-Petersburg State University, Faculty of applied mathematics and control processes, 198504 \\ Saint Petersburg, Russia \\ ${ }^{4}$ A.I. Barayev research and production Centre for grain farming, 021601 Shortandy-1, Republic of \\ Kazakhstan
}

\begin{abstract}
Under conditions of field production experiments, it was shown that the large-tonnage waste of hydrolysis production is the hydrolysis lignin (HL), which can act not only as a source of organic matter in organic or organic-mineral fertilizers, but also serve as a matrix for microorganisms, contributing to improvement of phytosanitary state of soils. It was shown that HL not only contributes to improvement of physicochemical properties of soils and replenishment of humus reserves, but also increases the resistance of plants to diseases, providing a yield increase by $10-20 \%$. In this regard, the integrated use of HL with microbiological compounds is of particular interest. It was revealed that use of HL in combination with bacterial compound - "Mizorin", provided a statistically significant yield increase ( $2 \mathrm{t} / \mathrm{ha}$ or $6.6 \%)$. At the same time, the plants' damage by common scab decreased from 0.75 to 0.46 points. The observed effect can be caused by the fact that the beneficial microflora, which is part of the "Mizorin" product, is significantly activated due to the branched matrix of lignin.
\end{abstract}

\section{Introduction}

The decisive role of lignin in the process of humification is known [1]. Based on the special role of lignin in the formation of soil humus, a conceptual model of organic and mineral interactions in soils has been developed [2]. In particular, it was shown that lignin phenols can even act as paleo-vegetation biomarkers in soils [3]. The heterogeneity of the lignin composition and the varying intensities of biochemical transformation under various environmental and climatic conditions provide the spatial complexity of soil organic matter [4-5]. Based on the development and application of a conceptual model of the role of lignin, specific mechanisms for the stabilization of organic matter in soils have been developed [67]. In the process of transformation of plant residues containing lignin in the soil, various carbon transformations are observed [8], various compounds are formed, including those that can affect the microflora of soils and pathogenic microorganisms. However, identifying such

${ }^{*}$ Corresponding author: Zelenydar@,mail.ru 
compounds under varying conditions is extremely difficult. Therefore, the phytopathogenic role of these compounds in the biocenosis is still insufficiently studied. It is especially important and relevant to study the possible effect of lignin compounds and lignin transformation products on pathogenic microflora in cultivation of plants.

The other side of the problem is that a huge amount of organic waste with a high lignin content is currently accumulated and continues to accumulate. Since lignin is very weakly mineralized and slowly included in the natural process of humification, any waste with a high lignin content is destined to accumulate and occupy vast territories around enterprises producing them for a long time. Among these industries is hydrolysis production, where hydrolysis lignin (HL) is a waste that is obtained from the production of hydrolysis alcohol and yeast biomass. The role of HL in plant nutrition and soil fertility was considered by us earlier [9]. In particular, it was shown that various compounds with biological activity can be formed from HL in the process of artificial thermochemical humification [10]. Thus, HL can be considered not only as a waste, but also as a valuable model compound for studying the processes of humus formation.

The objective of our research was to study the effect of hydrolysis lignin on phytosanitary state of soils during potato cultivation.

Use of wastes of hydrolysis production of $\mathrm{HL}$ as a means of improving the phytosanitary condition of soils is very relevant, but has not been studied much and has the prospect of developing both from the standpoint of recycling large-tonnage production wastes and of ensuring the quality of cultivated crops and the agroecological state of fields [9].

\section{Materials and methods}

Field experiments were carried out in production plantings of potatoes on the basis of a farm located in the Vyborg district of the Leningrad Oblast on sod-podzolic well-cultivated light loamy soils.

The object of the research was hydrolysis lignin (HL), which is a brown mass of organic lignin residues after isolation from plant materials (sawdust of conifers or deciduous species) of hydrolyzable compounds used to produce ethanol or yeast stillage. Before application to the soil, acid $\mathrm{HL}$ was neutralized with lime at the rate of $30-35 \mathrm{~kg}$ of $\mathrm{CaCO}_{3}$ per 1 ton of $\mathrm{HL}$ [9]. In the experiments, both pure (without neutralization) and previously neutralized HL were used.

The object for the impact of HL and products of its transformation on plants was several potato varieties that are cultivated in the Russian Federation. The experiments used zonal technology for growing potatoes, typical for the cultivation region.

HL was applied to the soil at doses of 30, 60, $90 \mathrm{t} / \mathrm{ha}$. In order to assess HL's impact on the phytosanitary state of soils, "Mizorin" and copper sulfate were used as comparison options.

"Mizorin" (a biological product of the "Ultravit group" with an active principle: Arthrobacter mysorens) was used for processing tubers before planting. The mechanism of action is manifested both due to fixation of atmospheric nitrogen and release of growthstimulating substances that accelerate development of plant's root system and enhance mineral nutrition of the culture, and also due to the fungicidal effect. Bacteria, activated by its composition, colonize the root system and plant tissues, causing a yield increase and increasing of resistance to diseases and stress (https://ekosspb.ru). "Mizorin" is widely used in agricultural practice [11].

Copper sulfate $\left(\mathrm{CuSO}_{4}\right)$ is one of the most common fungicides. The advantages of this product are the low cost and accessibility. The tool is used to combat potato late blight, starting in the late 19 th century. Also, copper sulfate protects plants from scab, early blight, 
black scurf, and other fungal diseases. The substance is toxic to adults and larvae of the Colorado potato beetle.

The experiments were carried out in a production environment. The area of each experimental plot is not less than 1 ha, accounting for $100 \mathrm{~m}^{2}$. Placement of experimental variant is continuous. When conducting field experiments and processing the results, we were guided by the field experiment methodology [12] and research methods in plant protection [13]. Statistical processing of research results (analysis of variance) was carried out using the Stat software package (https://www.softportal.com/software-9744-stat.html). Statistically significant results in the tables are highlighted in bold.

\section{Results and discussion}

It was established in experiments that HL increased the potato yield (from $11.6 \mathrm{t} / \mathrm{ha}$ with a dose of lignin $30 \mathrm{t} / \mathrm{ha}$; to $13.1 \mathrm{t} / \mathrm{ha}$ with a dose of HL $60 \mathrm{t} / \mathrm{ha}$; and up to $14.3 \mathrm{t} / \mathrm{ha}$ with a dose of lignin $90 \mathrm{t} / \mathrm{ha}$ ). In addition, when using lignin, the prevalence of potato diseases, such as macrosporiosis and late blight, was significantly reduced (Table 1). At the same time, the prevalence of macosporiosis decreased from $38 \%$ in the control variant and in the smalldosage variant (10 t/ ha). A significant decrease in potato damage by macrosporiosis, up to $30 \%$ was observed at a HL dose of $60 \mathrm{t} / \mathrm{ha}$, and up to $20 \%$ at a HL dose of $90 \mathrm{t} / \mathrm{ha}$, and these indicators were statistically significant. Late blight damage also decreased almost simultaneously with an increase in the HL dose. Moreover, at the maximum HL dose of 90 $\mathrm{t} / \mathrm{ha}$, the effect relative to the control variant was 2 times higher and statistically significant.

In general, both the biological effect (by $6.5 \ldots 32.6 \ldots 45.6 \%$ ) and the economic effect (by $8.2 \ldots 22.4 \ldots 33.6 \%$ ) increased with the increasing doses of lignin.

Table 1. Effect of the increasing HL doses on yield and phytosanitary condition of soils during potato cultivation.

\begin{tabular}{|c|c|c|c|c|c|c|}
\hline & \multicolumn{4}{|c|}{ Lignin dose, t/ha } & \multicolumn{2}{c|}{ Statistics } \\
\hline & 0 & 30 & 60 & 90 & $\mathrm{HCP}_{05}$ & $\mathrm{~F}_{\text {exp }} / \mathrm{F}_{\text {tab }}$ \\
\hline Yield, t/ha & 10.7 & 11.6 & $\mathbf{1 3 . 1}$ & $\mathbf{1 4 . 3}$ & 1.52 & $10.45 / 3.49$ \\
\hline Macrosporiosis, \% & 38 & 38 & $\mathbf{3 0}$ & $\mathbf{2 0}$ & 7.3 & $12.88 / 3.49$ \\
\hline Late blight, \% & 30 & 28 & $\mathbf{2 0}$ & $\mathbf{1 5}$ & 8.6 & $6.35 / 3.49$ \\
\hline
\end{tabular}

The following experiment illustrates the features of HL's impact and comparison preparations used for pickling potatoes before planting (vitriol and mizorin) on the morphological characteristics and potato yields (Table 2).

In order to more clearly indicate the role of $\mathrm{HL}$ as a means of reducing phytopathogenic damage to plants, we used the initially infected planting material in the following experiments, where the scab's damage ordinary exceeded the standards of GOST 7001-98 and amounted to $87 \%$. it was revealed that application of HL at a dose of $30 \mathrm{t} / \mathrm{ha}$ (Table 1 ) can be an effective tool against potato diseases. Moreover, its effectiveness was higher than even such common remedies as copper sulfate and "Mizorin". It was noted that the best results were obtained with the use of lignin and HL + "Mizorin", both in morphological indicators and in yield. These same variants provided a decrease in the level of phytopathogens (in this case, common scab) by almost $20 \%$ when using HL and up to $40 \%$ with a combination of HL with "Mizorin". In addition, the seedling phase on the HL + "Mizorin" variant began 5 days earlier than for all other variants, which indicates the positive effect of this combination on growth and development of potatoes.

In addition to lignin itself, its compositions with "Mizorin" and such a common remedy as copper sulfate (as the comparison means) were used in the next experiment, and the following results were obtained (Table 2). 
Means designed to reduce the potato damage by scab (copper sulfate and "Mizorin") did not have a positive effect on the susceptibility of plants to common scab, moreover, they even intensified the negative effect. The scab lesion score slightly decreased when using lignin (to 0.62 points versus 0.75 in the control variant). The greatest positive effect was manifested when using the composition of lignin and the biological product "Mizorin" at a dose of 1 $\mathrm{kg} / \mathrm{ha}$. The effect of this composition was provided by a significant reduction of potato diseases and yield increase. The highest statistically significant yield was obtained (increase of $2 \mathrm{t} /$ ha or $6.6 \%$ ) in this experimental variant. At the same time, the damage to plants by scab ordinary decreased from 0.75 to 0.46 points. The observed effect can be caused by the fact that the beneficial microflora, which is part of the "Mizorin" product, is significantly activated due to the branched matrix of lignin.

Table 2. Impact of HL and preplant treatment of tubers with compounds on morphological characteristics and yield of potatoes ("Vesna belaya" cultivar).

\begin{tabular}{|c|c|c|c|c|c|c|c|}
\hline $\begin{array}{c}\text { Experimental } \\
\text { variants }\end{array}$ & Dose & $\begin{array}{c}\text { Plant } \\
\text { height, } \\
\mathbf{m}\end{array}$ & $\begin{array}{c}\text { Number of } \\
\text { internodes, } \\
\text { pes }\end{array}$ & $\begin{array}{c}\text { Number } \\
\text { of } \\
\text { tubers } \\
\text { in 1 } \\
\text { plant }\end{array}$ & $\begin{array}{c}\text { Common } \\
\text { scab } \\
\text { damage, } \\
\text { points }\end{array}$ & $\begin{array}{c}\text { Yield, } \\
\text { t/ha }\end{array}$ & $\begin{array}{c}\text { Increasin } \\
\text { g of } \\
\text { control } \\
\text { variant } \\
\text { by, } \pm \%\end{array}$ \\
\hline Control & & 0.56 & 12.0 & 7.0 & 0.75 & 30.0 & 0 \\
\hline Copper sulfate & $0.2 \mathrm{~g} / \mathrm{l}$ & 0.54 & 11.2 & 6.2 & $\mathbf{1 . 2 0}$ & $\mathbf{2 7 . 0}$ & -10 \\
\hline Mizorin & $1 \mathrm{~kg} / \mathrm{ha}$ & 0.46 & 11.0 & 6.7 & 0.92 & 29.0 & -4.3 \\
\hline Lignin (HL) & $30 \mathrm{t} / \mathrm{ha}$ & 0.54 & 11.1 & 6.9 & 0.62 & 31.2 & +4.0 \\
\hline $\mathrm{HL}+$ Mizorin & $30 \mathrm{t} / \mathrm{ha}$ & 0.57 & 11.6 & 6.8 & $\mathbf{0 . 4 6}$ & $\mathbf{3 2 . 0}$ & +6.6 \\
\hline$+1 \mathrm{~kg} / \mathrm{ha}$ & & & & & 0.28 & 1.2 & \\
\hline $\mathrm{HPC}_{05}$ & & & & &
\end{tabular}

In an experiment where the increasing doses of lignin were used, it was found that the lignin base provided not only yield increase (acting as an ameliorant), but also contributed to a significant reduction in potato diseases. At the same time, an improvement in the state of plants was observed both by morphological characters and by accelerating growth processes. Moreover, this effect was manifested regardless of the varietal characteristics of potatoes.

Table 3. Lignin's impact on disease development for different varieties of potatoes.

\begin{tabular}{|c|c|c|c|c|c|}
\hline \multirow{2}{*}{\multicolumn{2}{|c|}{ Indicators }} & \multirow{2}{*}{\multicolumn{2}{|c|}{ Gatchinskiy }} & \multirow{2}{*}{\multicolumn{2}{|c|}{ Detskoselsky }} \\
\hline & & & & & \\
\hline & t/ha & $\begin{array}{c}\text { Control } \\
41.8\end{array}$ & $\begin{array}{c}\begin{array}{c}\text { HL } 30 \\
\text { t/ha }\end{array} \\
\mathbf{5 0 . 8}\end{array}$ & \multirow{2}{*}{$\begin{array}{c}\text { Control } \\
36.6 \\
\end{array}$} & \multirow{2}{*}{$\begin{array}{c}\text { HL } 30 \\
\text { t/ha } \\
41.9\end{array}$} \\
\hline & $\%$ & & & & \\
\hline \multirow{3}{*}{ Statistics } & & \multirow{2}{*}{\multicolumn{2}{|c|}{8.3}} & & \\
\hline & & & & \multirow{2}{*}{\multicolumn{2}{|c|}{$1.15 / 7.71$}} \\
\hline & $\mathrm{F}_{\text {exp }} / \mathrm{F}_{\text {ta }}$ & \multicolumn{2}{|c|}{$8.91 / 7.71$} & & \\
\hline \multicolumn{2}{|c|}{ Plant height, $\mathrm{cm}$} & 70,5 & 81.0 & 60.6 & 65.9 \\
\hline \multirow{6}{*}{$\begin{array}{c}\text { Disease } \\
\text { development }\end{array}$} & Late blight, $\%$ & 37 & 26 & 40 & 31 \\
\hline & $\mathrm{HCP}_{05}(\%)$ & \multicolumn{2}{|c|}{8.6} & \multicolumn{2}{|c|}{5.79} \\
\hline & $\mathrm{F}_{\mathrm{exp}} / \mathrm{F}_{\mathrm{tab}}$ & \multicolumn{2}{|c|}{$12.52 / 7.71$} & \multicolumn{2}{|c|}{$18.69 / 7.71$} \\
\hline & Common scab, points & 1.5 & 0.3 & 1.9 & 0.8 \\
\hline & $\mathrm{HCP}_{05}(\%)$ & \multicolumn{2}{|c|}{1.1} & \multicolumn{2}{|c|}{0.9} \\
\hline & $\mathrm{F}_{\text {exp }} / \mathrm{F}_{\text {tab }}$ & \multicolumn{2}{|c|}{$5.66 / 7.71$} & \multicolumn{2}{|c|}{$10.68 / 7.71$} \\
\hline \multirow[t]{2}{*}{ Efficacy, \% } & Biological & & 29.8 & & 22.5 \\
\hline & Economical & & 21.3 & & 14.2 \\
\hline
\end{tabular}


Assessing the effect of HL on the development of diseases of various potato varieties (Table 3), it can be noted that the introduction of lignin into the soil at a dose of $30 \mathrm{t} / \mathrm{ha}$ contributed to a reduction in late blight from $37-40 \%$ to $26-31 \%$, and scab from $1.5-1.9$ points to 0.3-0.8 points. As a result of field experiments, it was found that lignin and lignin composites with biological products provided an increase in yield (by 14-22\%), and also contributed to improvement of plant development and product quality. It was noted that in variants with lignin, the tops developed much better (plant height increased by $9-15 \%$ ), which contributed to improvement of photosynthetic potential and the outflow of assimilates to tubers. In addition, it is significant to improve the overall economic indicators: biological efficiency - up to $30 \%$ and financial - more than $20 \%$ ("Detskoselsky" cultivar).

According to recent publications [14], 17 biological products are currently used against potato diseases, mainly based on Bacillus subtilis and Trichoderma asperellum. However, information about their effectiveness is insufficient. The possibilities of maintaining their activity in a preparative form used in the form of dry and liquid biological products are not sufficiently developed. In order to increase the effectiveness of biological products, a multibioconversional solid-phase base of biological products (substrate) is proposed. The substrates are made on the basis of peat or sawdust with wheat bran [14]. Since the matrix in this substrate is a lignin base, we proposed to consider a different substrate based on a lignin matrix, such as hydrolytic lignin (HL).

The effectiveness of using HL as components of fertilizers and biological products has been shown in a number of works [9, 13-15] and others. Assessing the solutions to the problem of lignin waste, both Russian [15-18] and Ukrainian [19] scientists consider, first of all, their fertilizing properties. Regarding the symbiotic relationships of the lignin matrix with microorganisms, practical data are extremely limited [14]. Therefore, the presented work is innovative and it discusses previously unexplored results of the HL as an irregular polymer matrix that serves to activate microorganisms and the HL's impact capacity on phytosanitary state of soils, which is exemplified by growing potatoes.

The observations on the HL application in potatoes open up the prospect of using production wastes as new fertilizers with a phytosanitary effect.

Some ideas of optimization theory [20-21] were used in the paper.

\section{Conclusion}

As a result of field experiments with different varieties of potatoes, it was found that lignin and lignin composites with biological products provided an increase in yield (by 10-30\%), product quality, and also contributed to improvement of phytosanitary condition of soils. In addition, it improved the overall economic indicators significantly: biological efficacy - up to $30 \%$ and financial - more than $20 \%$. It was established that lignin, and especially composites of lignin with biological products, provided a comprehensive positive effect both on the soil, improving its physicochemical, phytosanitary, physiological and biological properties, and on plants as well, improving condition of the cultivated crop and stimulating growth and development of potatoes.

Consequently, large-tonnage wastes of hydrolysis production, such as HL, can be not only disposed, but also effectively used, as shown by the example of its use in the cultivation of potatoes, where HL contributed to crop yield increase and also had a high positive effect on phytosanitary condition of soil.

Of particular interest is the integrated use of HL and "Mizorin". It was on this experimental variant that the highest statistically significant yield was obtained (increased by 2 t/ha or $6.6 \%$ ). At the same time, the plants' damage caused by common scab decreased from 0.75 to 0.46 points. The observed effect can be caused by the fact that the beneficial 
microflora, which is part of the "Mizorin" compound, is significantly activated due to the branched matrix of lignin.

\section{References}

1. I. V. Kovalev, Biohimiya lignina v pochvah [Lignin biochemistry in soils] (Moscow, 2015)

2. M. Kleber, S. Sollins, R. A. Sutton, Biogeochemistry 85, 9 (2007). DOI: 10.1007/s10533-007-9103-5

3. N. O. Kovaleva, I. V. Kovalev, Eurasian Soil Science 9, 1073 (2015). DOI: $10.1134 / \mathrm{S} 1064229315090057$

4. J. Lehmann, D. Solomon, J. Kinyangi, L. Dathe, S. Wirick, C. Jacobsen, Nature Geosciences 1, 238 (2008). DOI: 10.1038/ngeo155

5. N. G. Lewis, L. B. Davin, Current Opinion in Biotechnology 16, 407 (2005). DOI: 10.1016/j.copbio.2005.06.011

6. M. Lützow, I. Kögel-Knabner, B. Ludwig, E. Matzner, H. Flessa, K. Ekschmitt, G. Guggenberger, B. Marschner, K. Kalbitz, Journal of Plant Nutrition and Soil Science 171, 111 (2008). DOI: 10.1002/jpln.200700047

7. M. W. I. Schmidt, M. S. Torn, S. Abiven, T. Dittmar, G. Guggenberger, I. F. Janssens, M. Kleber, I. Kögel-Knabner, J. Lehmann, D. A. C. Manning, P. Nannipieri, D. P. Rasse, S. Weiner, S. E. Trumbore, Nature 478, 49 (2011). DOI: 10.1038/nature10386

8. E. A. Webster, J. A. Chudek, D. W. Hopkins, Soil Biology and Biochemistry 32, 301 (2000). DOI: 10.1016/S0038-0717(99)00153-4

9. A. A. Komarov, The role of hydrolytic lignin in soil fertility and plant nutrition (Author's Abstract of Candidate of Science (PhD) Dissertation (Agricultural Science), Saint Petersburg, 2004)

10. A. A. Komarov, Eurasian Soil Science 38, 586 (2005)

11. T. M. Yaroshenko, D. Yu. Zhuravlev, N. F. Klimova, V. A. Kulikova, Tekhnologiya effektivnogo primeneniya bakterial'nyh preparatov dlya povysheniya produktivnosti sel'skohozyajstvennyh kul'tur v stepnoj zone Povolzh'ya [Technology for the effective use of bacterial preparations to increase crop productivity in the Volga steppe zone] (Federal State Government-Funded Scientific Institution Agricultural Research Institute of the South-East Region, Saratov, 2017)

12. B. A. Dospekhov, Metodika polevogo opyta (s osnovami statisticheskoj obrabotki rezul'tatov issledovanij) [Methods of field experience (with the basics of statistical processing of research results)] (Agropromizdat, Moskow, 1985)

13. Metody issledovanij v zashchite rastenij [Research methods in plant protection] (Saratov State Agrarian University, Saratov, 2014)

14. Yu. A. Titova, I. I. Novikova, I. V. Boykova, V. A. Pavlyushin, I. L. Krasnobaeva, Agricultural Biology 54, 1002 (2019). DOI: 10.15389/agrobiology.2019.5.1002rus

15. N. I. Romanchuk, The effect of organic and mineral fertilizer based on hydrolytic lignin on the fertility of sod-podzolic soils and productivity of the main agrocenoses of the middle taiga (Author's Abstract of Candidate of Science (PhD) Dissertation (Agricultural Science), Barnaul, 2008)

16. I. V. Volchatova, S. A. Medvedeva, M. V. Butyrin, L. A. Belovezhets, Eurasian Soil Science 5, 55 (2005) 
17. R. M. Nemeshev, Sovremennye problemy i perspektivy racional'nogo lesopol'zovaniya $v$ usloviyah rynka [Proceedings of international scientific-practical conference Current problems and prospects of rational forest management in a market environment] (SaintPetersburg State Forestry University, Saint-Petersburg, 2007)

18. S. M. Krutov, A. P. Voznyakovsky, I. V. Gribkov, I. V. Shugaley, Ekologicheskaya himiya 23, 145 (2014)

19. V. V. Simonova, T. G. Shendrik, B. N. Kuznetsov, Journal of Siberian Federal University. Chemistry 3, 340 (2010)

20. Zaitseva I., Poddubnaya N., Malafeyev O., Vanina A., Novikova E. 2019 Solving a dynamic assignment problem in the socio-economic system Journal of Physics: Conference Series https://doi.org/10.1088/1742-6596/1172/1/012092

21. Zaitseva I and Malafeyev O and Kolesin I and Ermakova A and Shlaev D 2018 Modeling of the labour force redistribution in investment projects with account of their delay (Proc. ICPCSI) p. 68-70. 